\title{
Effects of angiotensin converting enzyme inhibition on sodium excretion in patients with hypoxaemic chronic obstructive pulmonary disease
}

\author{
A G Stewart, J C Waterhouse, C G Billings, P Baylis, P Howard
}

\begin{abstract}
Background - Some patients with hypoxaemic chronic obstructive pulmonary disease (COPD) develop cor pulmonale with sodium and water retention. The sodium retention has been explained as a result of increased plasma levels of aldosterone. If this was true angiotensin converting enzyme (ACE) inhibition would be expected to lower plasma levels of aldosterone and improve the renal excretion of sodium.

Methods - Six patients with stable hypoxaemic COPD $\left(\mathrm{PaO}_{2}<8.0 \mathrm{kPa}\right)$ and a history of an oedematous exacerbation received an intravenous hypertonic saline load $(6 \mathrm{ml} / \mathrm{kg}$ body weight of $2.7 \%$ saline over one hour) before and while taking $4 \mathrm{mg} /$ day perindopril, an ACE inhibitor, for one month. Aldosterone, antidiuretic hormone $(\mathrm{ADH})$, plasma and urine electrolyte levels, osmolality, and volume were measured over four hours. The repeatability of the saline load test was assessed in six patients with a similar severity of hypoxaemic COPD. For comparison the saline load test was also performed in six patients with mild COPD.
\end{abstract}

Results - The hypertonic saline load test results were repeatable. Perindopril reduced the mean (SD) plasma level of aldosterone from $142(88) \mathrm{pg} / \mathrm{ml}$ to 54 (24) $\mathrm{pg} /$ $\mathrm{ml}$ at 0 minutes before the saline infusion, and from $64(35) \mathrm{pg} / \mathrm{ml}$ to $30(17) \mathrm{pg} / \mathrm{ml}$ after the infusion without improving the urinary volume or sodium excretion. Before starting treatment with perindopril $43.7(6.9) \mathrm{mmol}(20 \%)$ of the sodium load was excreted compared with 49.6 (7.9) $\mathrm{mmol}(22 \%$ of load) when taking perindopril. Patients with mild COPD excreted more sodium $(77.6(21.4) \mathrm{mmol}$ (38.7\% of load)) despite having similar plasma aldosterone levels to those in the patients receiving perindopril.

Conclusions - Patients with stable hypoxaemic COPD have an impaired ability to excrete sodium which is not improved by the administration of an ACE inhibitor. ACE inhibition lowered the plasma level of aldosterone without improving sodium excretion. This suggests that the inability of patients with hypoxaemic COPD to excrete sodium is not caused by their increased plasma levels of aldosterone.
Patients with hypoxaemic chronic obstructive pulmonary disease (COPD) who develop oedema have a poor prognosis. ${ }^{1}$ Their cardiac output is usually normal or increased, ${ }^{2}$ whilst their renal blood flow is reduced ${ }^{3}$ and excretion of water and salt loads is impaired..$^{4-7} \mathrm{Ab}$ normalities in secretion of antidiuretic hormone $(\mathrm{ADH})$ and activation of the renin-angiotensinaldosterone system have been found in some patients with COPD. ${ }^{4-6}$

The development of oedema in patients with COPD is associated with stimulation of the renin-angiotensin-aldosterone axis and increased ADH release. ${ }^{68}$ The raised aldosterone levels may contribute to sodium retention and the increased $\mathrm{ADH}$ levels to hyponatraemia. However, rather than being the cause of the oedema in hypoxaemic COPD, these changes might reflect other aspects of the disease such as a further reduction in renal blood flow, altered intrarenal haemodynamics, the stress of the disease, or even the effects of treatment with drugs such as diuretics.

If the activation of the renin-angiotensinaldosterone system with increased levels of angiotensin II and aldosterone was the major determinant of the sodium retention seen in hypoxaemic COPD, its blockade by an angiotensin converting enzyme (ACE) inhibitor should improve the ability of these oedematous patients to excrete a hypertonic saline load.

\section{Methods}

Nine patients with stable hypoxaemic COPD, with current or recent peripheral oedema and documented increase of the jugular venous pressure, were chosen from patients attending the chest clinic. Patients with other causes of oedema such as heart disease, liver disease, renal disease, and those with known hormonal disorders or diabetes mellitus were excluded.

These nine patients underwent a hypertonic saline load test before and whilst taking perindopril, an ACE inhibitor, at a dose of $4 \mathrm{mg}$ / day (including the day of the test). The saline load protocol was almost identical to that used in other studies in COPD. ${ }^{79}$ Perindopril was started at a dose of $1 \mathrm{mg}$ daily immediately after the first saline load test. The dose was increased to $2 \mathrm{mg} /$ day and then $4 \mathrm{mg} /$ day at fortnightly intervals. Pulse and blood pressure were monitored half hourly for two hours after the first and at each incremental dose. Patients remained on $4 \mathrm{mg} /$ day for one month before the second saline load. 
Table 1 Reproducibility of the effects of hypertonic saline loading in six patients with hypoxaemic COPD

\begin{tabular}{|c|c|c|c|}
\hline & $\begin{array}{l}\text { First sodium load } \\
(\text { mean }(S D))\end{array}$ & $\begin{array}{l}\text { Second sodium load } \\
\text { (mean) }\end{array}$ & $\begin{array}{l}\text { Coefficient of } \\
\text { repeatability }\end{array}$ \\
\hline $\begin{array}{l}\text { Age (years) } \\
\mathrm{FEV}_{1}(\mathrm{l}) \\
\mathrm{FVC}_{(1)} \\
\mathrm{PaO}_{2}(\mathrm{kPa}) \\
\mathrm{PaCO}_{2}(\mathrm{kPa})\end{array}$ & $\begin{array}{r}66 \cdot 7(3 \cdot 5) \\
1.1(0 \cdot 4) \\
2 \cdot 6(1 \cdot 0) \\
7 \cdot 8(0 \cdot 6) \\
6 \cdot 4(0 \cdot 6)\end{array}$ & & \\
\hline $\begin{array}{l}\text { After hypertonic saline l} \\
\text { Urine volume }(\mathrm{ml}) \\
\mathrm{Na} \text { excretion }(\mathrm{mmol}) \\
\% \text { load excreted }\end{array}$ & $\begin{array}{c}287 \\
58 \cdot 9 \\
25 \cdot 7\end{array}$ & $\begin{array}{r}277 \\
55 \cdot 0 \\
25 \cdot 2\end{array}$ & $\begin{array}{c}46 \\
9 \cdot 7 \\
3 \cdot 8\end{array}$ \\
\hline $\mathrm{GFR}(\mathrm{ml} / \mathrm{min})$ & 92 & 100 & $19 \cdot 4$ \\
\hline $\begin{array}{l}\text { Serum sodium (mmol } \\
0 \mathrm{~min} \\
60 \mathrm{~min}\end{array}$ & $\begin{array}{l}143 \\
149 \cdot 5\end{array}$ & $\begin{array}{l}144 \\
149 \cdot 5\end{array}$ & $\begin{array}{l}5 \cdot 2 \\
4 \cdot 8\end{array}$ \\
\hline $\begin{array}{l}\text { Serum osmolality (mo } \\
0 \mathrm{~min} \\
60 \mathrm{~min}\end{array}$ & $\begin{array}{l}293 \\
301\end{array}$ & $\begin{array}{l}294 \\
302 \cdot 6\end{array}$ & $\begin{array}{l}6 \cdot 9 \\
7 \cdot 8\end{array}$ \\
\hline $\begin{array}{c}\text { Plasma aldosterone }(p \\
0 \mathrm{~min} \\
60 \mathrm{~min} \\
240 \mathrm{~min}\end{array}$ & $\begin{array}{r}111 \\
72 \\
92\end{array}$ & $\begin{array}{r}102 \\
58 \\
74\end{array}$ & $\begin{array}{l}29 \\
32 \\
40^{*}\end{array}$ \\
\hline
\end{tabular}

${ }^{*} \mathrm{p}<0.05$.

Table 2 Mean (SD) effects of perindopril, $4 \mathrm{mg}$ daily, on the ability to excrete a $2 \cdot 7 \%$ saline load

\begin{tabular}{|c|c|c|c|}
\hline & $\begin{array}{l}\text { Before } \\
\text { perindopril }(n=6)\end{array}$ & $\begin{array}{l}\text { After } \\
\text { perindopril }(n=6)\end{array}$ & Controls $(n=6)$ \\
\hline 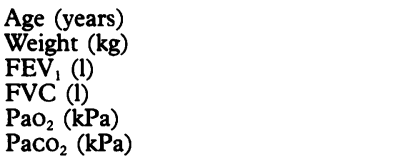 & $\begin{array}{l}66 \cdot 6(5 \cdot 7) \\
83 \cdot 0(14 \cdot 6) \\
1 \cdot 0(0 \cdot 4) \\
2 \cdot 2(0 \cdot 7) \\
7 \cdot 1(0 \cdot 9) \\
6 \cdot 1(0 \cdot 5)\end{array}$ & $\begin{array}{l}66 \cdot 8(5 \cdot 7) \\
83 \cdot 1(14 \cdot 1) \\
1 \cdot 0(0 \cdot 4) \\
2 \cdot 2(0 \cdot 8) \\
7 \cdot 3(0 \cdot 8) \\
6 \cdot 2(0 \cdot 5)\end{array}$ & $\begin{array}{c}69.0(2.5) \\
74.0(7.3) \\
1.7(0.6) \\
3.6(0.7) * \\
9.7(0.6) \\
4.9(0.4)\end{array}$ \\
\hline $\begin{array}{l}\text { Urinary volume }(\mathrm{ml}) \\
\text { Sodium excretion (mmol) } \\
\text { Sodium excreted (\% load) }\end{array}$ & $\begin{array}{r}285(70) \\
43 \cdot 7(6 \cdot 9) \\
20 \cdot 1(4 \cdot 5)\end{array}$ & $\begin{array}{l}313(93) \\
49 \cdot 6(7 \cdot 9) \\
22 \cdot 2(2 \cdot 3)\end{array}$ & $\begin{array}{l}382(68)^{*} \\
77 \cdot 6(21 \cdot 4)^{* *} \\
38 \cdot 7(9 \cdot 9)^{* * *}\end{array}$ \\
\hline $\begin{array}{l}\text { GFR }(\mathrm{ml} / \mathrm{min}) \\
\text { Fractional sodium reabsorption }(\%) \\
\text { Free water clearance }(\mathrm{ml} / \mathrm{min})\end{array}$ & $\begin{array}{l}75 \cdot 1(21 \cdot 1) \\
98 \cdot 6(0 \cdot 4) \\
-1 \cdot 1(0 \cdot 2)\end{array}$ & $\begin{array}{l}73 \cdot 3(23 \cdot 3) \\
98 \cdot 3(0 \cdot 6) \\
-1 \cdot 1(0 \cdot 3)\end{array}$ & $\begin{array}{r}92.7(21.0) \\
97.3(1.0)^{*} \\
-1.8(0.5)^{*}\end{array}$ \\
\hline $\begin{array}{l}\text { Urine osmolality (start) } \\
\text { Urine osmolality (end) } \\
\text { Urine sodium (start) } \\
\text { Urine sodium (end) }\end{array}$ & $\begin{array}{l}665(139) \\
671(102) \\
114(23) \\
160(20)\end{array}$ & $\begin{array}{l}630(138) \\
644(99) \\
119(32) \\
166(32)\end{array}$ & $\begin{array}{l}714(86) \\
723(138) \\
144(38) \\
211(32)\end{array}$ \\
\hline $\begin{array}{l}\text { Serum sodium }(\mathrm{mmol} / \mathrm{l}) \\
0 \mathrm{~min} \\
60 \mathrm{~min} \\
240 \mathrm{~min}\end{array}$ & $\begin{array}{l}141(4 \cdot 0) \\
148(5 \cdot 0) \\
143(2 \cdot 2)\end{array}$ & $\begin{array}{l}143(2 \cdot 4) \\
147(1 \cdot 9) \\
145(3 \cdot 2)\end{array}$ & $\begin{array}{l}143(1 \cdot 9) \\
148(2 \cdot 1) \\
146(1 \cdot 8)\end{array}$ \\
\hline $\begin{array}{l}\text { Serum osmolality (mosmol/l) } \\
0 \mathrm{~min} \\
60 \mathrm{~min} \\
240 \mathrm{~min}\end{array}$ & $\begin{array}{l}287(10 \cdot 3) \\
300(9 \cdot 5) \\
293(4 \cdot 2)\end{array}$ & $\begin{array}{l}285(4 \cdot 0) \\
297(7 \cdot 0) \\
291(4 \cdot 4)\end{array}$ & $\begin{array}{l}289(7 \cdot 0) \\
295(6 \cdot 7) \\
289(5 \cdot 6)\end{array}$ \\
\hline $\begin{array}{l}\text { Aldosterone }(\mathrm{pg} / \mathrm{ml}) \\
0 \mathrm{~min} \\
60 \mathrm{~min} \\
240 \mathrm{~min}\end{array}$ & $\begin{array}{r}147(84) \\
64(35) \\
107(95)\end{array}$ & $\begin{array}{l}58(22) \dagger \\
30(12) \dagger \\
37(17)\end{array}$ & $\begin{array}{l}63(30)^{*} \\
40(29) \\
37(24)\end{array}$ \\
\hline $\begin{array}{c}\text { ADH }(\mathrm{pmol} / \mathrm{l}) \\
0 \mathrm{~min} \\
60 \mathrm{~min} \\
240 \mathrm{~min}\end{array}$ & $\begin{array}{l}4 \cdot 6(3 \cdot 3) \\
8 \cdot 4(4 \cdot 9) \\
7 \cdot 9(3 \cdot 9)\end{array}$ & $\begin{array}{l}3 \cdot 6(3 \cdot 3) \\
5 \cdot 6(3 \cdot 8) \\
6 \cdot 7(3 \cdot 4)\end{array}$ & $\begin{array}{l}2 \cdot 2(2 \cdot 4) \\
4 \cdot 7(2 \cdot 9) \\
3 \cdot 4(3 \cdot 1)\end{array}$ \\
\hline
\end{tabular}

${ }^{*} \mathrm{p}<0.05,{ }^{* *} \mathrm{p}<0.01,{ }^{* * *} \mathrm{p}<0.001$ by ANOVA on all three groups.

$+\mathrm{p}<0.05$ before perindopril $v$ on perindopril (paired $t$ test)

Four patients were receiving diuretics which were stopped for three days before saline loading but continued between saline loads (with the exception of one patient who was on spironolactone, $100 \mathrm{mg}$ daily, which was stopped).

Before the test the patients ate a conventional diet and were fasted overnight. On the saline load days they attended the laboratory at 09.00 hours and were weighed. Spirometric tests (Vitalograph Compact) were performed and the patients then emptied their bladders, the urine being collected for measurement of osmolality and electrolytes. Blood pressure (sphygmomanometer), pulse and oxygen saturation by a pulse oximeter (Ohmeda Biox
3700) were recorded. Patients remained comfortably seated throughout the salt load test.

Blood samples for measurement of urea, electrolytes (Technicon SMAC analyser), and osmolality (Advance osmometer 2WII) were collected into serum tubes, and plasma samples for $\mathrm{ADH}$ and aldosterone assay into tubes containing ethylenediaminetetra-acetate (EDTA). The EDTA tubes were centrifuged immediately and the plasma removed and frozen at $-20^{\circ} \mathrm{C}$ until assayed. Samples were taken at the following times: $-30,0,60,120,180$, and 240 minutes after the saline infusion.

Between 0 and 60 minutes the subjects received a $2 \cdot 7 \%(3 \mathrm{~N})$ saline $(450 \mathrm{mmol} / \mathrm{l})$ intravenous infusion at a constant rate of $0.1 \mathrm{ml} /$ $\mathrm{kg} / \mathrm{min}$. Blood pressure and oxygen saturation were recorded at each time point. After four hours arterial blood gases were taken, the patients emptied their bladders, urine volume was noted, and urine excretion of sodium and creatinine and urine osmolality were measured.

Creatinine clearance was calculated over the 4.5 hours of the test and used as a measure of the glomerular filtration rate. Filtered sodium ( $\mathrm{mmol} / \mathrm{min}$ ) was calculated by multiplying the glomerular filtration rate by the plasma sodium concentration. Fractional sodium reabsorption was calculated by dividing excreted sodium $(\mathrm{mmol} / \mathrm{min})$ by the filtered sodium and subtracting from one; the fraction was expressed as a percentage.

Plasma aldosterone levels were measured with SB-ALDO radioimmunoassay kits (CIS Bio International, Cedex, France). These have a limit of detection of $15 \mathrm{pg} / \mathrm{ml}$ and a quoted normal range of $15-150 \mathrm{pg} / \mathrm{ml}$ supine and $35-300 \mathrm{pg} / \mathrm{ml}$ upright.

Antidiuretic hormone was analysed by a described radioimmunoassay. ${ }^{10}$ The assay has a limit of detection of $0.3 \mathrm{pmol} / 1$, an intra-assay coefficient of $9.7 \%$, and an interassay coefficient of $15 \cdot 3 \%$ at $2 \mathrm{pmol} / \mathrm{l}$.

Two patients developed severe chest infections during this period and did not complete the study and one person withdrew for personal reasons. The results of the remaining six patients have been compared by a paired $t$ test.

As a comparison six patients with mildly hypoxaemic COPD and no history of oedema also received the same saline load test. These results were compared with the two sets of data from the perindopril treated patients by ANOVA with Scheffe's test.

Reproducibility of the test was assessed in six patients with similar severity of COPD (on the basis of $\mathrm{FEV}_{1}$ and $\mathrm{PaO}_{2}$ values) to those who were involved in the perindopril study. This included three patients involved in the perindopril study. These patients undertook two saline load challenges three months apart (before receiving perindopril in the three patients). Their results were compared by the method of Bland and Altman. ${ }^{11}$

The study was approved by the ethical committee of the Sheffield Health Authority. All patients gave consent freely after the aims and requirements of the study had been explained. 


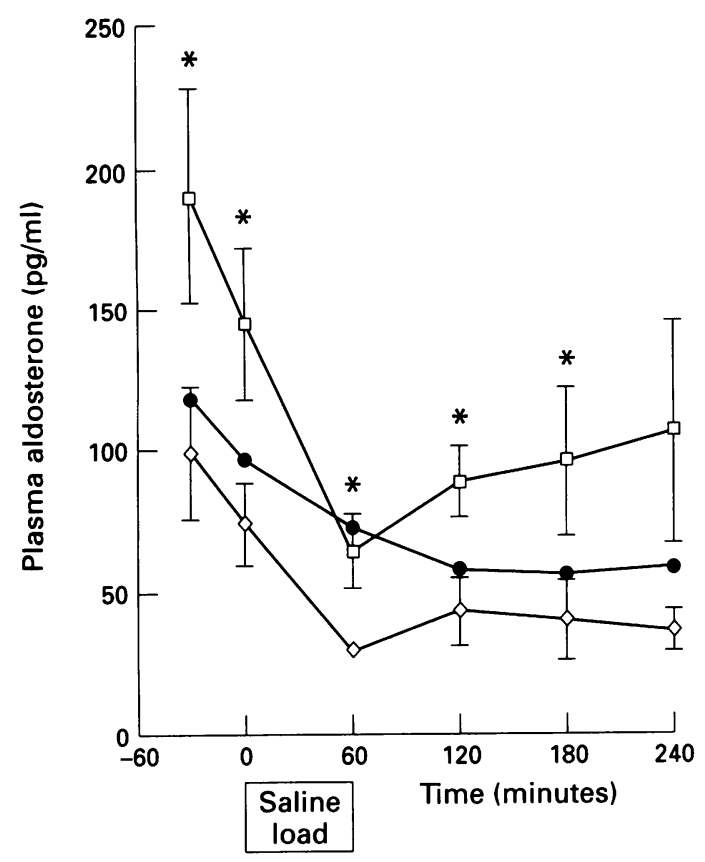

Figure 1 Mean (SE) plasma aldosterone levels in six patients with COPD during a $6 \mathrm{ml} / \mathrm{kg}$ intravenous $2.7 \%$ saline load before perindopril $(\square)$, and on perindopril $4 \mathrm{mg} /$ day $(\diamond) .95 \%$ confidence levels $(\bigcirc)$ for the upper limit of plasma aldosterone level derived from age matched control patients with COPD; normal aldosterone range in supine patients is $15-150 \mathrm{pg} / \mathrm{ml}$. ${ }^{*} p<0.05$.

\section{Results}

Table 1 shows the reproducibility of the protocol. With the exception of aldosterone levels at 240 minutes the differences in the two readings were not significant. Patient characteristics were similar in both control and perindopril study subjects (mean $\mathrm{FEV}_{1} 1 \cdot 1(0.4) 1$ and $1.0(0 \cdot 4) 1$ respectively, and mean $\mathrm{PaO}_{2} 7 \cdot 8(0 \cdot 6)$ $\mathrm{kPa}$ and $7 \cdot 1(0.9) \mathrm{kPa}$ respectively). In the patients with severely hypoxaemic COPD the effects of hypertonic saline loading were satisfactorily reproducible in terms of sodium and water excretion, serum sodium levels and osmolality changes, and plasma aldosterone levels at the beginning of the study challenges.

Before taking perindopril the patients with oedematous hypoxaemic COPD had levels of aldosterone significantly higher than the control group at -30 and 0 minutes. However, these results were within the quoted normal ranges. Aldosterone levels fell appropriately during the intravenous hypertonic saline load (fig 1).

No adverse reactions to perindopril were reported. The drug produced a significant lowering of aldosterone $(p<0.05)$ (fig 1$)$ at all time points with the exception of 240 minutes but, despite this, there was no improvement in sodium excretion (table 2). Likewise the volume of urine excreted did not increase on perindopril. The levels of $\mathrm{ADH}$ were insignificantly lower on the perindopril day (fig 2). The levels of both these hormones whilst on perindopril were similar to values obtained in control patients with mild COPD $\left(\mathrm{FEV}_{1}\right.$ $1.7(0.6) 1$ and $\mathrm{PaO}_{2} 9.7(0.6) \mathrm{kPa}$ ) (figs 1 and 2). These controls excreted significantly greater amounts of sodium and water $(\mathrm{p}<0.05)$ (table 2). Likewise, perindopril did not alter the fractional sodium reabsorption, serum sodium levels, urinary or plasma osmolality, or glomerular filtration rate.

\section{Discussion}

Our study has shown that dynamic saline load experiments are reproducible in patients with hypoxaemic COPD and confirmed that stable oedematous hypoxaemic patients with COPD have a significantly impaired ability to excrete a sodium load. ${ }^{5-79}$ Plasma aldosterone levels were greater than those seen in the control group before the saline challenge but were within the quoted normal range for this assay and did suppress appropriately during the hypertonic saline load. The changes in the first half hour reflect the change from an upright active state to a rested sitting position. The aldosterone levels were similar to previous studies in patients with stable COPD, ${ }^{56}$ but were less than has been reported in some acutely oedematous patients. ${ }^{569}$ As in previous studies $^{56}$ mean plasma ADH levels were higher than expected.

Chronic ACE inhibition by perindopril reduced plasma aldosterone levels in the oedematous patients to levels seen in nonoedematous, less severely affected patients with COPD. Despite this significant fall in aldosterone levels there was no improvement in the ability of the oedematous patients to excrete a sodium load. This suggests that the raised plasma levels of aldosterone found in patients with stable oedematous COPD are not the main cause of their impaired ability to excrete a saline load. These results also suggest that long term ACE inhibition may be ineffective in the chronic management of oedematous cor pulmonale.

In the acute situation, however, particularly in decompensated oedematous exacerbations where aldosterone levels are high, ${ }^{5}$ ACE inhibition might prove therapeutically useful. In an acute study a single $25 \mathrm{mg}$ dose of captopril given to a comparable group of patients with hypoxaemic COPD receiving a similar hypertonic saline load did marginally improve

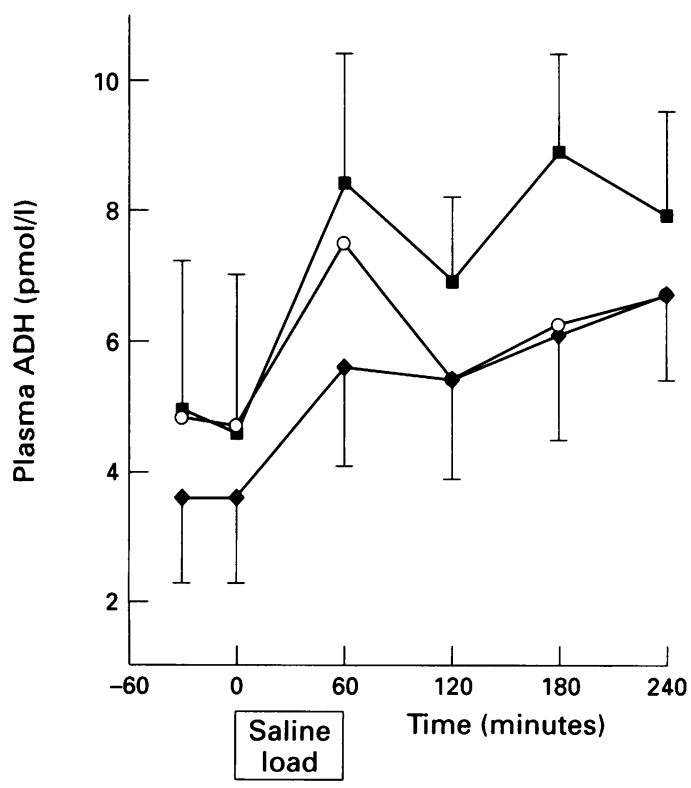

Figure 2 Mean (SE) plasma antidiuretic hormone $(A D H)$ levels in six patients with COPD during a $6 \mathrm{ml} / \mathrm{kg}$ intravenous $2 \cdot 7 \%$ saline load before perindopril $(\square)$, and on perindopril $4 \mathrm{mg} /$ day $(\diamond) .95 \%$ confidence levels $(\mathrm{O})$ for the upper limit of plasma $A D H$ level derived from age matched control patients with COPD. 
sodium excretion. ${ }^{9}$ The fact that the patients were rendered normoxic by supplemental oxygen throughout the experiment might also account for the differences from our study. However, such acute studies should not be compared with chronic treatment where the many limbs of these complex homeostatic reflexes will compensate for the alteration in any one part of the regulatory mechanism.

The lack of effect of ACE inhibition in improving sodium excretion in patients with oedematous hypoxaemic COPD is reminiscent of the lack of effect of captopril in nephrotic syndrome, a condition which is also associated with sodium and water retention and a stimulation of the renin-angiotensin-aldosterone system. ${ }^{12}$ It is probable that the increase in aldosterone levels is more an effect of the disease process than the cause.

The small increases in urine volume and sodium excretion seen in patients on perindopril were within the levels of test reproducibility. It is possible that in a much larger group the small improvement in sodium excretion might have reached significance. Such a small increase in excretion would, however, be too small to be important. It comprises only a very small part of the impairment in sodium and water excretion seen in these patients with cor pulmonale.

The failure of ACE inhibition to increase sodium excretion is not due to a concomitant fall in atrial natriuretic peptide. Levels of atrial natriuretic peptide are raised in cor pulmonale and increase further on hypertonic saline loading. ${ }^{7}$ Alternatively, the opposing effects of systemic and intrarenal angiotensin II might explain these findings. Intrarenal angiotensin II maintains the glomerular filtration rate via efferent arteriolar vasoconstriction. Reduction in angiotensin II might lower the glomerular filtration rate and would be expected to reduce sodium excretion. The lack of change in the glomerular filtration rate, despite systemic evidence for ACE inhibition, suggests that intrarenal angiotensin II is not the only cause of the efferent glomerular vasoconstriction needed to maintain the glomerular filtration rate in hypoxaemic COPD. ${ }^{13}$

Renal blood flow was not measured in this study. Captopril ${ }^{14}$ given to a comparable group of patients produced a highly significant fall in levels of angiotensin II and an increase in a low effective renal plasma flow from $281 \mathrm{ml} / \mathrm{min}$ at baseline and $296 \mathrm{ml} / \mathrm{min}$ on captopril, without any change in glomerular filtration rate. Such changes might be expected to produce a small natriuresis, as the decrease in filtration fraction would reduce colloid osmotic pressure in the peritubular capillaries and thus reduce sodium and water reabsorption from the proximal convoluted tubule. ${ }^{15}$ However, these changes would have been small compared with the overall impairment in effective renal plasma flow and the considerable inability to excrete sodium.

On perindopril the lower plasma ADH levels did not quite reach significance. ACE inhibition, however, has been shown to lower plasma ADH levels in congestive cardiac failure. ${ }^{16}$
This study did not assess the effects of ACE inhibition on the frequency of oedematous decompensations, nor did it measure improvement in well being, dyspnoea, or exercise tolerance. Such improvements have been seen with perindopril in congestive cardiac failure. ${ }^{17}$ It is possible, however, for these benefits to occur without improvement in natriuresis and diuresis. ${ }^{18}$

In conclusion, in oedematous hypoxaemic patients with COPD the ACE inhibitor perindopril lowered the levels of plasma aldosterone without improving their impaired ability to excrete a hypertonic saline load. This suggests that the chronic increase in aldosterone levels seen in patients with oedematous hypoxaemic COPD is not the prime cause of the impaired ability to excrete a sodium load. The increased levels of aldosterone might be an effect of hypoxaemic COPD or the treatment - for example, diuretics. However, this study does not rule out the possibility that increased levels of aldosterone may be important during acute oedematous exacerbations and that, under these acute situations, ACE inhibition might have a beneficial therapeutic effect.

1 Renzetti AD, McClement JH, Litt BD. The Veterans Administration Cooperative Study of Pulmonary Function III. Mortality in relation to respiratory function in chronic obstructive pulmonary disease. Am $\mathcal{F}$ Med 1966;41:11529.

2 Macnee W. Right ventricular function in cor pulmonale. Cardiology 1988;75SI:30-40.

3 Platts MM, Hammond JDS, Stuart-Harris $\mathrm{CH}$. A study of cor pulmonale in patients with chronic bronchitis. $Q \mathcal{F}$ Med 1960;116:559-74.

4 White RJ, Woodings DF. Impaired water handling in chronic obstructive airways disease. BMF 1971;2:561-3.

5 Farber MO, Roberts LR, Weinberger MH, Robertson GL Fineberg NS, Manfredi F. Abnormalities of sodium and water handling in chronic obstructive lung disease. Arch water handling in chronic obst

6 Farber MO, Manfredi F. Mechanisms of hyponatremia and edema in chronic obstructive pulmonary disease: clinica significance. Pract Cardiol 1984;10:105-31.

7 Stewart AG, Bardsley PA, Baudoin SV, Waterhouse JC Thompson JS, Morice AH, et al. Changes in atrial natriuretic peptide concentrations during intravenous saline infusion in hypoxic cor pulmonale. Thorax 1991; 46:829-34.

8 Farber MO, Kiblawi SS, Strawbridge RA, Robertson GL. Studies on plasma vasopressin and the renin angiotensin aldosterone system in chronic obstructive lung disease. f Lab Clin Med 1977;90:373-80.

9 Farber MO, Weinberger MH, Robertson GL, Fineberg NS The effects of angiotensin converting enzyme inhibition on sodium handling in patients with advanced chronic obstructive pulmonary disease. Am Rev Respir Dis 1987; 136:862-6.

10 Rooke P, Baylis PH. A new sensitive radioimmunoassay for plasma arginine vasopressin. $\mathcal{F}$ Immunoassay $1982 ; 3$ 115-31.

11 Bland JM, Altman DG. Statistical methods for assessing agreement between two methods of clinical measurement. Lancet 1986; i:307-11.

12 Brown EA, Markandu ND, Saquella ?, Macgregor FA. Lack of effect of captopril on the sodium retention of the nephrotic syndrome. Nephron 1984;37:43-7.

13 Canon PJ. The kidney in heart failure. N Engl f Med 1977; 296:26-32.

14 Oliver RM, Peacock AJ, Fleming JS, Waller DG. Renal and pulmonary effects of angiotensin converting enzymes in chronic hypoxic lung disease. Thorax 1989;44:513-5.

15 Vander AM, Malvin RL, Wilde WS, Sullivan LP. Reexamination of the salt and water retention in congestive cardiac failure: significance of renal filtration fraction. $A m$ f Med 1958;25:497-501.

16 Bichet DG. Water disturbance in cardiac failure. Ballieres $\mathcal{f}$ Endocrinol 1989;3.2:559-74.

17 Bounhoure JP, Bottineau G, Lechat P, Garnham J, Lapeyre $G$. Value of perindopril in the treatment of chronic congestive cardiac failure. Clin Exp Theory Pract 1989;A11, gestive cardiac

18 Maslowski AH, Ikram H, Nicholls MG, Espiner EA Haemodynamic, hormonal and electrolyte responses to captopril in resistant heart failure. Lancet 1981;i:71-3. 